\section{Emojis como nova estratégia de captação no discurso publicitário}

\author{
Emojis as a new strategy of capturing in advertising \\ discourse
}

\author{
Marcia Figueiredo de Assis Terra (D) 9 \\ mafaterra@gmail.com
}

Universidade Federal Fluminense - UFF

\section{Ilana da Silva Rebello (i) 9}

ilanarebello@id.uff.br

Universidade Federal Fluminense - UFF

\section{Resumo}

Hoje, a cada instante, somos surpreendidos com os avanços na área de comunicação que, consequentemente, afetam a linguagem. A publicidade é o meio de comunicação em massa que se reinventa e busca comunicar de maneira cada vez mais eficaz e sedutora, renovando-se, constantemente, ao adotar novas estratégias. Presentes em nossas conversas diárias em redes sociais e em aplicativos de conversa instantânea, os emojis captam os consumidores, justamente por serem para a publicidade uma forma criativa e divertida de apresentar um produto ou uma marca. Tendo isso em mente, o presente trabalho tem por objetivo investigar a função dos emojis e os imaginários sociodiscursivos evocados em duas peças publicitárias, veiculadas entre os anos de 2015 e 2018, sob à luz da teoria Semiolinguística de Análise do Discurso, desenvolvida por Patrick Charaudeau. Para tal análise, serão consideradas as noções de sujeitos do ato de linguagem, o processo de semiotização do mundo, o contrato de comunicação, bem como a noção de imaginários sociodiscursivos. A análise preliminar vem demonstrando que, ao serem utilizados, a partir de imaginários que o interlocutor tem do social, os emojis configuram uma estratégia de captação. Por fim, com este trabalho, esperamos contribuir com as pesquisas no campo da comunicação humana e das ciências da linguagem.

\section{Palavras-chave}

Semiolinguística; Publicidade; Emojis.

\section{Abstract}

Today, every moment, we are surprised by the advances in the area of communication, which consequently affect the language. Advertising is the means of mass communication that, aware of these changes, reinvents itself and seeks to communicate in an increasingly effective and seductive way, renewing itself constantly when adopting new strategies. Present in our daily conversations on social networks and instant chat apps, emojis capture consumers because they are for advertising a creative and fun way to present a product or a brand. With this in mind, the present work aims to investigate the role of emoji in the advertising message and the sociodiscursive imaginaries evoked from the analysis of two advertising pieces run between the years 2015 and 2018, under the light of the Semiolinguistic theory of Analysis of Discourse, developed by Patrick Charaudeau. For this analysis, the notions of subjects of the language act, the World Semiotization Process, Communication Contract, as well as the notion of Sociodiscursive Ima-

\section{Linguagęm Foco}

Revista do Programa de Pós-Graduação em Linguistica Aplicada da UECE

FLUXO DA SUBMISSÃO

Submissão do trabalho: 10/06/2020 Aprovação do trabalho: 19/08/2020 Publicação do trabalho: 25/09/2020

\section{COMO CITAR}

TERRA, Marcia Figueiredo de Assis; REBELLO, Ilana da Silva. Emojis como nova estratégia de captação no discurso publicitário. Revista Linguagem em Foco, v.12, n.2, 2020. p. 333 - 354. Disponível em: https://revistas.uece.br/index.php/linguagememfoco/article/view/4022. 
ginaries will be considered. The preliminary analysis has shown that, when used, from the imaginary that the interlocutor has of the social, the emojis configure a strategy of capturing. Finally, with this work, we hope to contribute to researches in the field of human communication and language sciences.

Keywords

Semiolinguistic; Publicity; Emojis.

\section{Introdução}

Atualmente, vivemos na era digital, na qual informação e acontecimento são registrados e propagados numa velocidade jamais vista. O imediatismo nas decisões e relações imposto pela doutrina neoliberal, que rege as sociedades ocidentais, conduziu o homem a um meio de comunicação igualmente rápido com efeitos de possibilitar a globalização.

A cibercultura que emana desse contexto sócio-histórico vem, aos poucos, rompendo com as fronteiras da comunicação e propiciando o surgimento de uma nova linguagem. Com isso, nos últimos anos, o meio publicitário tem se ajustado e se beneficiado dessa nova forma de comunicar justamente pela sua capacidade de se moldar consoante os desígnios de seus consumidores, assim como ocorre na relação linguagem-comunidade.

Nesse sentido, neste trabalho, temos por objetivo analisar como a estrutura da mensagem publicitária é construída a partir de argumentação icônico-linguística com os emojis e quais imaginários sociodiscursivos são evocados.

Assim, para alcançarmos os objetivos, na sequência, a partir dos postulados da Teoria Semiolinguística de Análise do Discurso, discorreremos sobre os sujeitos e o contrato de comunicação, o processo de semiotização de mundo, os imaginários sociodiscursivos, já estabelecendo relação com o gênero em análise - a publicidade. Também discorreremos sobre os pictogramas, o emojis e o emoticons, e sobre a força da linguagem publicitária na vida das pessoas. Após essa parte teórica, no tópico "Análise", abordaremos, com mais detalhes, duas peças publicitárias, a partir da fundamentação teórica estudada.

\section{Os sujeitos do ato de linguagem e o contrato de comunicação}

A Semiolinguística é uma teoria de Análise do Discurso, proposta pelo linguista Patrick Charaudeau. De acordo com a teoria, o sujeito é um ser biopsicossocial, dotado de saberes, de intencionalidade e de competência. $O$ ato de linguagem envolve, no mínimo, quatro sujeitos, dois eus e dois tus, chamados de 
Eu-comunicante, Eu-enunciador, Tu-interpretante e Tu-destinatário. (CHARAUDEAU, 2001).

O Eu-comunicante e o Tu-interpretante são parceiros, sujeitos reais, sociais, com identidade biopsicossocial, que interagem no circuito externo, no espaço do fazer. O Eu-enunciador e o Tu-destinatário são sujeitos discursivos, protagonistas, que atuam no circuito interno, no espaço do dizer.

No texto publicitário, o EU comunicante-publicista define-se como instância comunicante responsável pelo projeto de palavra publicitário, voltado a um destinatário imaginário, o TU interpretante-consumidor, em razão de um objeto de compra, o produto.

No circuito interno, atuam o EU-anunciante e o TU-destinatário. O EU-anunciante não se revela como publicista. Ele constrói uma imagem de enunciador que é responsável por apresentar o produto-marca. O TU-destinatário é o consumidor potencial, ou seja, ele pode vir a consumir o produto ou não e esse produto, por vezes, pode ter seu nome ocultado, sobressaindo apenas a marca, como no caso de CHEVROLET, ao invés de nomear o produto como carro.

Para Charaudeau (2009), uma vez que há os sujeitos falantes (do circuito externo) e os sujeitos do discurso (do circuito interno), suas identidades também possuem duplo caráter: a identidade psicossocial e a identidade discursiva. A primeira, pertencente ao sujeito comunicante, é constituída por um conjunto de traços: sexo, idade, profissão, estatuto, lugar hierárquico, suas qualidades afetivas e sua legitimidade para falar. A segunda pertence ao sujeito enunciador e é construída pelo sujeito comunicante, por meio das estratégias (de credibilidade e de captação) de como falar. A identidade discursiva é o modo de tomada da palavra.

Nesse sentido, um dos princípios que rege o ato de linguagem é o de alteridade: a tomada de consciência de si mesmo através da existência do outro. As identidades são construídas através de um "cruzamento de olhares" entre os parceiros da troca. Eles se reconhecem e se diferenciam, legitimando-se e legitimando o outro. Uma vez percebida a diferença, um duplo processo de atração e rejeição é desencadeado. A atração acontece porque, ao descobrirmos alguém diferente de nós, admitimos a nossa imperfeição. Paralelamente, a rejeição ocorre quando a diferença percebida no outro é vista como uma ameaça, quando aventamos a possibilidade de o outro ser superior. Essa é a razão pela qual a diferença vem acompanhada, na maior parte das vezes, de uma generalização, de um julgamento estereotipado. 
Para objer êxito em seu ato de linguagem, o Eu-comunicante, no papel de Eu-enunciador, utiliza estratégias de legitimidade, de credibilidade e de captação.

As estratégias de legitimação dizem respeito àquelas estratégias utilizadas pelo sujeito, a fim de mostrar ao destinatário que está apto a desempenhar uma determinada identidade social. A credibilidade é a necessidade que o sujeito tem de que se acredite nele. O Eu-comunicante deve preservar seu ethos (imagem de si). Para tal, ele pode adotar uma das seguintes atitudes discursivas: (I) de neutralidade - apagamento de qualquer vestígio de avaliação pessoal ou julgamento em seu discurso; (II) de distanciamento - o sujeito distancia-se, tomando uma atitude fria, típica do analista que raciona e analisa imparcialmente para explicar fatos e/ou demonstrar teorias, e (III) de engajamento - o sujeito posiciona-se, escolhendo palavras ou argumentos. Essa atitude é utilizada quando o sujeito deseja criar uma imagem de "ser de convicção". A verdade confunde-se com a força da convicção, de modo que se espera influenciar o interlocutor.

As estratégias de captação são utilizadas quando o sujeito falante não se encontra em posição de autoridade em relação ao seu interlocutor e deseja assegurar-se de que este compartilha das mesmas opiniões, tocando-o afetivamente. A persuasão e a sedução' são os efeitos visados pelo Eu-comunicante. Assim, diferentes atitudes discursivas podem ser tomadas: (I) de polêmica - quem comunica questiona o interlocutor a respeito das ideias em foco; (II) de sedução - o Eu-comunicante propõe um mundo imaginário no qual o interlocutor desempenharia o papel de "herói beneficiário", e (III) de dramatização - o sujeito descreve fatos relacionados aos dramas da vida, fazendo uso de analogias, comparações e outras figuras de linguagem. Adotando essa atitude, o Eu-comunicante deseja "fazer sentir" através de valores afetivos socialmente compartilhados.

Assim, a fim de conquistar a atenção do público, o contrato de comunicação publicitária toma como alvo a emoção e os sentimentos do sujeito consumidor, por meio de estratégias discursivas que passam pela visada de captação (fazer sentir) e pela visada de informação (fazer saber). Por outro lado, a utilização das estratégias de credibilidade coloca o sujeito comunicante em posição de verdade, conferiando-Ihe seriedade ao apresentar determinado produto. Em determinados momentos, uma visada pode predominar sobre a outra a depender dos efeitos desejados pela instância publicitária.

Para que a interação flua, é necessário que os sujeitos sociais, parceiros da

1 A persuasão e a sedução objetivam o controle do outro. Porém, persuadir é "fazer pensar recorrendo à razão" e seduzir é "fazer sentir recorrendo à emoção". (CHARAUDEAU, 2009, p. 10). 
troca, reconheçam um ao outro o direito à fala e que compartilhem os saberes que circulam no ato de troca linguageira, dentro de uma situação comunicativa que os sobredetermina. Esses parceiros possuem certa liberdade que Ihes permite o uso de estratégias dentro de um espaço de restrições. Dessa forma, um ato de linguagem comporta dois espaços: um espaço de estratégias, que corresponde às escolhas possíveis, e o espaço das restrições, "que são as condições mínimas às quais é necessário atender para que o ato de linguagem seja válido" (CHARAUDEAU, 2005, p.13). Por exemplo, o gênero publicitário apresenta restrições que devem ser seguidas a fim de que o texto seja reconhecido como um exemplar do gênero, mas também permite a utilização de estratégias (escoIha de imagem, de cor, de ambiente...) que propiciarão a captação do interlocutor. Obviamente, as restrições formais não são as únicas do gênero publicitário. Aquele que comunica deve levar em consideração outros fatores da situação de comunicação, como quem são os interlocutores, se o canal de transmissão é gráfico ou oral, se os conhecimentos são comuns etc.

$O$ ato de linguagem é comparado a uma mise en scène, uma encenação que traz a marca da intencionalidade, na qual o sujeito, um ser psicossocial, dotado de saberes e competências, assume o papel de protagonista e, por meio de estratégias discursivas - de legitimidade, de credibilidade e de captação, vai elaborar seu projeto de comunicação. Pode-se dizer que o ato de linguagem é, portanto, uma aventura, um "jogo de expectativas", visto que o sucesso do projeto advém quando o efeito visado pelo locutor é o mesmo efeito produzido no interlocutor. Para tal, o sujeito comunicante usará dos contratos de comunicação.

No contrato publicitário, por exemplo, o Eu-comunicante constrói uma imagem de benfeitor por meio da enunciação, posicionando-se como aquele que pode oferecer o produto de que o Tu-interpretante precisa ou deseja, construindo uma imagem de um Tu-destinatário beneficiário do produto em questão. O ritual de abordagem, meio pelo qual o locutor vai entrar em contato com o interlocutor, ocorre, em geral, através de slogans.

Uma vez que o discurso publicitário é fundado no ato de oferecer, cabe ao Eu-comunicante colocar em cena estratégias discursivas adequadas para garantir a consolidação de seus objetivos e ao Tu-interpretante aceitá-las ou não. Veremos, adiante, que esses objetivos constituem as visadas discursivas (CHARAUDEAU, 2004). No contrato de comunicação publicitário, normalmente, essas visadas podem ser de incitação, de persuasão e de sedução.

Assim, no circuito externo do discurso publicitário, temos o Eu-comuni- 
cante, o anunciante relacionando-se com o Tu-interpretante, consumidores presumidos do produto divulgado. No circuito interno, encontram-se as produções discursivas, nas quais o Eu-enunciador e o Tu-destinatário protagonizam a interação.

A seguir, observaremos que tal como o ato de linguagem, o processo de semiotização de mundo possui caráter duplo, por meio do qual ocorre a construção de sentido.

\section{O processo de semiotização do mundo}

Charaudeau (2005) postula que o processo de semiotização, ou seja, o fenômeno de construção de sentido, realizado pelo sujeito psicossocial, tem um caráter duplo: processo de transformação, que transforma um "mundo a significar" em "mundo "significado" e processo de transação que torna esse "mundo significado" em objeto de troca com outro sujeito. O processo de transformação acontece sob a ação do Eu-comunicante que transforma o "mundo a significar" em "mundo significado". O processo de transação é o lugar da troca entre o Eu-comunicante e o Tu-interpretante. Assim, ambos os processos são solidários.

O processo de transformação envolve quatro tipos de operação que ocorrem no âmbito linguístico:

a) a identificação: os seres do mundo são nomeados para que deles se possa falar, transformando-se em identidades nominais. Nos textos publicitários, os produtos são identificados pelo nome da marca (M) como Omo, Nescafé, Coca-Cola.

b) a qualificação: os seres do mundo possuem qualidades e características que os especificam. São transformados em identidades descritivas, conforme o interesse do enunciador em atribuir-Ihes propriedades objetivas ou uma apreciação subjetiva.

Embora não seja obrigatório, o uso da qualificação constitui uma estratégia importante de construção textual, aplicada, principalmente, no gênero publicitário, ao descrevermos favoravelmente determinado objeto. Tal fato conduz o leitor à apreciação valorativa do mesmo, por exemplo: Novo Chevrolet Cruze; Intel processadores rápidos e confiáveis; Omo imbatível na remoção de manchas; SBP eficiente contra o mosquito do Zika.

c) a ação: os seres agem e sofrem ações que Ihes conferem a razão de ser ou de fazer. São transformados em identidades narrativas. Nos textos publicitários, a ação, normalmente, é descrita no modo imperativo: Divida Coca-Cola, Pre- 
pare para se apaixonar pelo novo Crevolet Cruze, Diga isso com Pepsi.

d) a causação: os seres agem ou sofrem a ação, tendo como causa certos motivos que os colocam numa cadeia de causalidade. Os acontecimentos do mundo são transformados (relatados) em "relações de causalidade" como no slogan: L'Óreal Paris porque você vale muito.

Ainda no processo de semiotização de mundo, há o processo de transação entre os sujeitos. Esse processo é regido por quatro princípios:

a) princípio de alteridade: concerne à identidade dos parceiros, a semeIhanças e a diferenças que ocorrem entre eles. São semelhantes por compartiIharem saberes e diferentes porque cada qual desempenha um papel distinto no ato de linguagem: sujeito emissor-produtor, o Eu-comunicante e o sujeito receptor-interpretante, o Tu-interpretante.

b) princípio de pertinência: está relacionado aos saberes, ao propósito temático. Faz-se mister que os parceiros compartilhem e considerem o conhecimento de mundo, os comportamentos e os valores. $O$ ato de linguagem deve adequar-se ao contexto.

c) princípio de influência: este princípio apresenta relação direta com a finalidade, visto que todo sujeito produtor do ato de linguagem tem a finalidade de atingir o sujeito receptor.

d) princípio de regulação: relacionado ao princípio de pertinência, diz respeito às estratégias utilizadas dentro de uma situação.

Na cena publicitária, normalmente, o princípio de alteridade é demarcado quando o Eu-enunciador se coloca como um bom conselheiro ao apresentar o produto para o Tu-destinatário, por ele projetado. A depender do produto, projetam-se variadas imagens de um receptor, podendo ele ser: conservador, moderno, jovem, maduro, homem, mulher, etc. O princípio de pertinência orienta a interpretação do consumidor. No slogan "L'Óreal Paris porque você vale muito", para que o enunciado produza sentido, faz-se necessário que ambos os sujeitos da encenação conheçam previamente a marca de produtos para cuidados dos cabelos. O princípio de influência procura envolver e afetar emocionalmente o interlocutor e o princípio de regulação relaciona-se às estratégias, pois são essas que regulam e permitem a inter-compreensão. No enunciado: "Prepare para se apaixonar pelo novo Chevrolet Cruze", o Eu-enunciador procura seduzir e emocionar o Tu-destinatário. Tal estratégia mostra-se flagrante pela escolha do verbo "apaixonar-se".

Dessa forma, afirmamos que $\mathrm{o}$ ato de linguagem desdobra-se em dois 
processos: o processo de transformação, que diz respeito às escolhas linguísticas feitas pelo Eu-comunicante, e o processo de transação, que comanda a significação, ou melhor, a transformação do mundo.

O processo de transformação não acontece isoladamente, mas de acordo com uma situação imposta pelo processo de transação, que pode ser entendido como um contrato de comunicação, no qual agem os implícitos a serem codificados.

Outra noção pertinente ao ato de linguagem diz respeito às visadas discursivas. Estas correspondem a um jogo de expectativas, cujo objetivo é alcançado quando os efeitos visados são percebidos pelo sujeito interpretante. Entendidas como atitudes enunciativas, elas se definem por um duplo critério: a intenção do eu e a posição que o tu deve ocupar.

Cabe ressaltar que não há uma relação direta entre uma situação de comunicação e uma visada. Uma única situação pode evocar uma ou mais visadas. E uma mesma visada pode ser encontrada em diversas situações. No discurso publicitário, há o predomínio da visada de incitação, pois o fazer crer, juntamente com o fazer apreciar o objeto - que é a potencial solução de seus problemas, a busca de um ideal de vida - é essencial para o sucesso desse tipo de contrato.

Na próxima seção, analisaremos como os imaginários sociodiscursivos influem na elaboração da mensagem publicitária.

\section{Os imaginários sociodiscursivos e os sistemas de pensamento}

Diferente do seu emprego corrente como aquilo que se opõe à realidade, o imaginário, segundo Charaudeau (2013), é uma imagem da realidade, capaz de interpretá-la e atribuir-lhe significações. $\bigcirc$ imaginário nasce na mecânica das representações sociais e constrói a significação sobre fenômenos, objetos, seres humanos e seus comportamentos. Em outras palavras,

\footnotetext{
ele resulta de um processo de simbolização do mundo da ordem do afetivo-racional através da intersubjetividade das relações humanas, e se deposita na memória coletiva. Assim, o imaginário possui uma dupla função de criação de valores e de justificação da ação. (...) (CHARAUDEAU, 2017, p.578)
}

Nesse sentido, à medida que a simbolização do mundo acontece dentro de um domínio de prática social (política, religiosa, publicitária, artística), o imaginário é social, conforme propôs Castoriadis (2000 apud CHARAUDEAU, 2013). Desse modo, ele torna coerente a relação entre a ordem social e as condutas, 
que são consolidadas pelas instituições. O imaginário social compõe, portanto, a identidade de um grupo.

Além disso, tendo em vista que os imaginários se manifestam por meio de enunciados linguageiros, são qualificados como sociodiscursivos. Cabe salientar que os imaginários não são todos conscientes. Alguns podem ser racionalizados em discursos que circulam nas instituições, enquanto outros, encontrados nos julgamentos implícitos transmitidos pelos enunciados, circulam nas sociedades. Originam-se de sistemas de pensamento, que são os saberes ordenados em sistemas de conhecimento e de crença que fornecem uma explicação global sobre o mundo e sobre o ser humano, e que se configuram, por sua vez, em tipos de saberes. Esses tipos de saberes podem criar teorias, doutrinas ou ideologias.

As teorias são constituídas de saberes de conhecimento ou de saberes científicos. Elas são fundadas em certezas que formam um conjunto de proposições que têm valor de postulados, princípios ou máximas, dos quais dependem os conceitos, os modos de raciocínio e o instrumental metodológico. Embora seja um saber fechado em si mesmo, o saber de conhecimento pode ser objeto de refutações ao ser confrontado com proposições contrárias ou resultados contraditórios. Nesse caso, pode-se dizer que as teorias são obrigadas a aceitar a confrontação pela observação ou pela crítica.

As doutrinas são constituídas em parte pelo saber de conhecimento e em parte pelo de crença. O saber de conhecimento procede de um modo de descrição ou de explicação centrado no mundo, independente do ponto de vista do sujeito. A crença procede do olhar que o sujeito tem sobre a legitimidade dos eventos e das ações do homem.

O fato de a Terra girar em torno do Sol é indiscutível porque é uma explicação dada pelo saber de conhecimento ou científico. Já o fato de Deus ajudar aqueles que acordam cedo consiste em uma crença ou saber que não pode ser provado. É um saber que se encontra no sujeito, portador de um julgamento. Na realidade, é um saber de opinião, visto que é baseado no posicionamento de um indivíduo à luz do que ele acredita ser verdade. Assim, muitos slogans publicitários são criados a partir de opiniões que se tornam "máximas": "Se é Bayer, é bom!", "Tomou Doril, a dor sumiu".

As doutrinas também podem ser fundadas em um saber de revelação. É um saber fechado, que recusa a crítica e, diante dela, os líderes dessas doutrinas reagem por meio de excomunhões ou outras exclusões. Seu discurso é apresentado sob a forma de evidência por um mediador que possui um caráter mais ou 
menos sagrado (um profeta, um sacerdote, um guru). Enunciados como: "Jesus é o filho de Deus, o Verbo encarnado", "Amai-vos uns aos outros", fazem menção a uma verdade revelada. O interlocutor tanto pode aderi-la como rejeitá-la, sob o risco de ser excluído do grupo que nela crê.

Por último, as ideologias constituem os saberes genéricos que propõem uma explicação total ou globalizante da atividade social. "A ideologia é um sistema de pensamento mais ou menos fechado sobre ele próprio e que é construído em torno de valores de um grupo social que se impõe" (CHARAUDEAU, 2013, p. 201).

Assim, por meio dos tipos de saberes apresentados, os imaginários sociodiscursivos são alimentados, jogando muitas vezes com essas categorias: fazendo um saber de crença passar por um saber de conhecimento, um saber de opinião por um saber de revelação e assim por diante.

No discurso publicitário, encontramos o imaginário do público para o qual o produto se destina, manifestando a forma como a sociedade enxerga o mundo sob a expressão da ideologia dominante. Como exemplo, há uma década, as propagandas de produtos de limpeza utilizavam apenas a figura feminina, pois, no imaginário coletivo, de um modo geral, a realização de tarefas domésticas sempre foi atribuída à mulher. Atualmente, notamos a presença masculina em comerciais desse segmento, evidenciando uma mudança nos imaginários sociais.

Observaremos, no tópico a seguir, que os emojis, devido ao seu emprego em conversas informais, muitas vezes, representando emoções, são utilizados como estratégia de captação em textos publicitários, evocando determinados imaginários sociais.

\section{Pictogramas, emojis e emoticons}

Os pictogramas são as formas mais antigas de comunicação visual. Devido à globalização, com o intuito de transmitir informação de forma rápida e acurada sem palavras, o uso de pictogramas, que mesmo antes do advento da internet já estabelecia um ponto de contato em diferentes idiomas, tornou-se uma marca da linguagem digital. Em seu artigo Design and evaluation of public information symbols, Dewar (1999) define pictogramas como:

representações gráficas de conceitos por meio de síntese visual utilizados para transmitir mensagens para grandes audiências. Eles são para informação pública e, geralmente, projetados para serem eficazes, sem o uso de palavras, bem como para serem lidos de forma rápida e precisa (DEWAR, 1999, p. 285). 
Os novos meios de comunicação inseriram novos códigos à linguagem, promovendo maior dinamicidade na transmissão de informação. Assim, o aprimoramento constante da tecnologia de mensagens de texto desenvolveu recursos visuais para agilizar o processo de comunicação.

Nesse contexto, surgem os emoticons e smileys, pictogramas criados para o universo da comunicação digital, e que evoluíram para os emojis na era da comunicação móvel. Eles reproduzem visualmente e de maneira análoga expressões, sentimentos e gestos, substituindo palavras, expressões e até sentenças inteiras quando combinados.

Enquanto os emoticons (do inglês "emotion" e "icon", em português "emoção" e "ícone", respectivamente) são símbolos criados essencialmente a partir da combinação de caracteres tipográficos que representavam sentimentos :-) :-(;-), os smileys são as representações desses caracteres em forma de desenhos (i) 2 (-). Com a introdução dos dispositivos móveis, surgiram os emojis (do japonês "e" e "moji", em português "imagem" e "personagem", respectivamente), trazendo, além dos pictogramas que representavam emoções, uma vasta biblioteca de figuras prontas, excluindo, assim, os sinais tipográficos.

Figura 1- Os primeiros emojis criados em 1999.

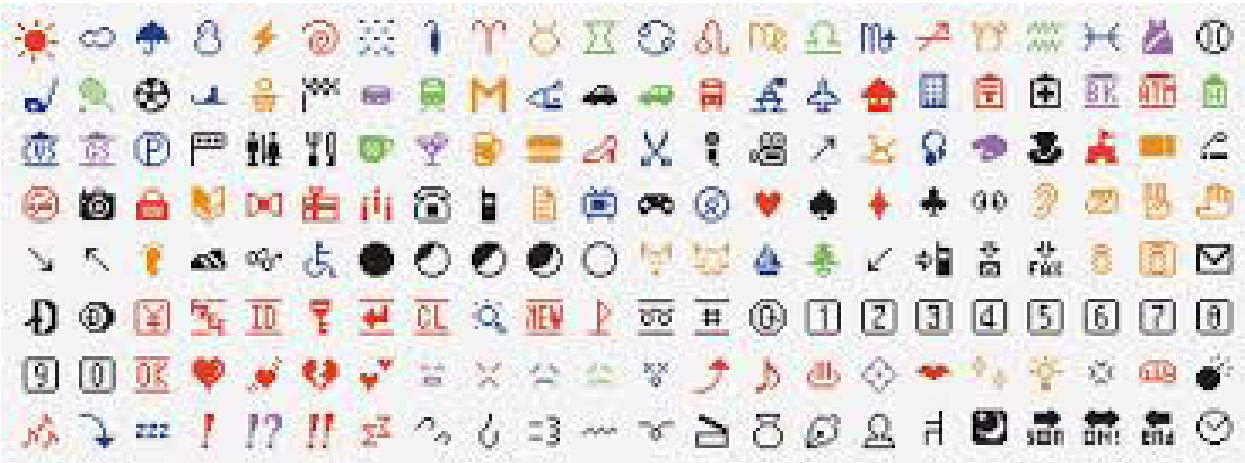

Fonte: https://www.wired.com/2016/10/new-yorks-moma-acquires-first-ever-pixelated-emoji/

Figura 2- Alguns emojis atuais.

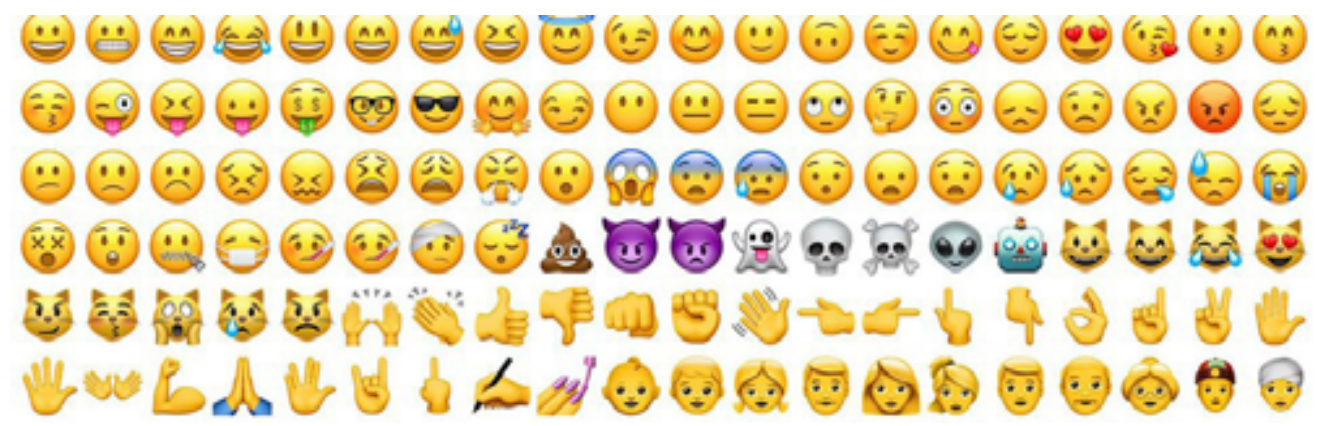

Fonte: https://lzgmkt.com.br/como-usar-emojis-em-acoes-de-marketing-digital/ 
Definidos como ferramenta de comunicação pelo seu desenvolvedor Shigetaka Kurita, os emojis, criados para a companhia telefônica japonesa NTT Docomo, uma década antes de serem lançados pela Apple, tornaram-se populares a todos que usam aplicativos de troca de mensagens de comunicação instantânea. O grupo Unicode, formado por programadores, gerencia a codificação para que as imagens possam ser lidas por várias linguagens globais e, assim, possam circular rapidamente pela Internet sem se perderem na tradução.

Embora as sociedades letradas tenham sido organizadas para adquirirem informação por meio do sentido da visão, em fevereiro de 2016, a empresa de teIefonia Telecom Italia Mobile (Tim), em parceria com o Instituto Benjamin Constant (IBC), lançou os Emoti Sounds, um projeto inovador, cujo objetivo foi tornar essa nova linguagem mundial em uma linguagem inclusiva. Os Emoti Sounds são uma ferramenta de acessibilidade digital baseada em emoticons e feita especialmente para deficientes visuais.

Desse modo, em paralelo com as pinturas rupestres e os hieróglifos, pode-se afirmar que os emojis são representações pictográficas, que se traduzem em fenômenos de comunicação e de cultura, já que modificam a linguagem e as práticas sociais. Entretanto, seu significado pode variar de acordo com o contexto e com a cultura de determinado grupo.

\section{Figura 3-Emoji}

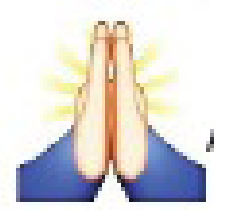

Fonte: http://www.iemoji.com/view/emoji/70/smileys-people/folded-hands

O emoji da figura 3 representa um tipo de cumprimento muito comum na cultura americana, o high-five? ${ }^{2}$ No Japão, tem sido usado como agradecimento e, como prece, por muitas pessoas no Brasil. Isso corrobora o fato de a linguagem visual ser culturalmente específica, segundo afirmam Kress; Van Leeuwen (1996).

Nos últimos anos, a linguagem publicitária tem se apropriado de forma muito criativa de elementos da web, levando-os para o texto impresso ou para o vídeo. Os emojis não são meras ilustrações, pois, junto com o texto em áudio ou com o texto escrito, fazem emergir, de forma muito criativa, uma rede complexa 
de sentidos. O banco Itaú, desde 2015, vem utilizando emojis para compor o texto publicitário, mostrando que o diferencial do banco é a presença da tecnologia, atuando sempre em favor do cliente.

Figura 4- Peça publicitária do banco Itaú, 2015.

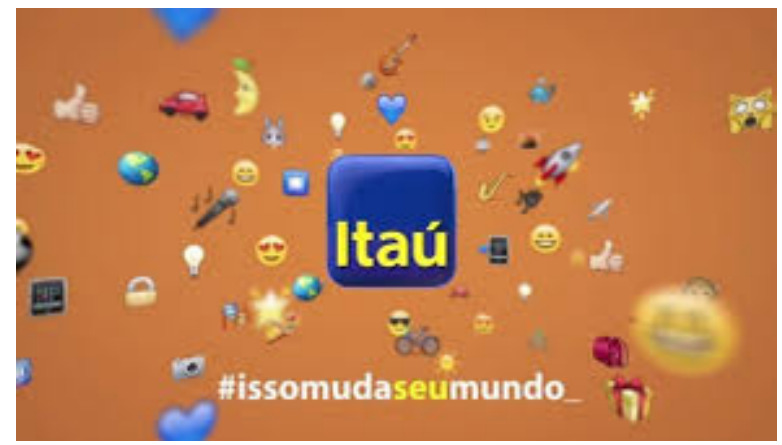

Fonte: <https://geekpublicitario.com.br/7394/itau-lanca-comerciais-feitos-apenas-com-emojis/> Acesso em 30/05/2018.

Nota-se que essa mescla entre texto verbal e não verbal com emojis tornou-se recorrente tanto em publicidades nacionais quanto internacionais. A seguir, examinaremos os mecanismos utilizados na construção da mensagem publicitária.

\section{A força da linguagem publicitária}

O que há por trás de mensagens publicitárias entremeadas de imagens, cores em technicolor e jingles que adquirem poder de mantras sem que atentemos para isso? As empresas publicitárias estariam, de fato, imbuídas de um espírito social e ético conforme nos fazem crer? Seria a sedução apenas uma estratégia sem grandes consequências? Afinal, as empresas descrevem em seus sites valores e princípios alinhados com os de seus consumidores. Mas quem são os consumidores nessa encenação? São pessoas que de fato precisam preencher sua falta existencial bebendo Coca-Cola? A promessa de uma sociedade mais evoluída residiria na aquisição de um carro da Ford?

Não se pode negar que a publicidade se renova constantemente e é justamente isso que a torna atraente e, em certa medida, democrática ao pensar que ela é utilizada para se dirigir a qualquer tipo de público. O contrato publicitário joga com o fracasso e com o sucesso por se direcionar a um grande número de pessoas, portanto, a distintas identidades. No entanto, o que se mantém intacto 
nesse jogo é a intenção do Eu-comunicante.

Nesse sentido, a palavra é o principal meio de acesso entre a instância publicitária e o público. Se nos primeiros momentos a linguagem publicitária possuía um caráter informativo, atualmente, é marcada pela visada de incitação, de "fazer crer". Seu poder não consiste apenas em vender tal marca, mas em envolver o consumidor à sociedade de consumo. Desse modo, a mensagem é construída partindo do princípio de "falta" de determinado atributo que o consumidor não possui. Ela explora os desejos, levando o consumidor a atravessar vários níveis:

Gráfico 1 - Etapas que levam à compra do produto

Desconhecimento $\rightarrow$ conhecimento $\rightarrow$ compreensão $\rightarrow$ convicção $\rightarrow$ ação (compra do produto) Fonte: Monnerat $(2003,15)$.

De acordo com Monnerat (2003, p. 36), existem três grupos de mecanismo de persuasão: mecanismos automáticos, de racionalização e de sugestão.

Os mecanismos automáticos agem sobre a memória, fazendo com que a marca seja memorizada em meio a muitos concorrentes. Com o aumento no número de publicidades, esse tipo de mecanismo deixa de ser eficiente porque é superficial. Logo, não age no psicológico do interlocutor.

Os mecanismos de racionalização constroem um raciocínio a partir de uma proposição seguida de um benefício para o consumidor. Muitas vezes, a publicidade utiliza esse tipo de mecanismo, mostrando as qualidades do produto para depois apresentar suas vantagens e benefícios.

Por último, a sugestão induz o consumidor à aceitação de uma crença específica, sem dar razões. Trata-se de um poderoso mecanismo de persuasão. A sugestão pode atuar por prestígio (quando vem de uma pessoa conceituada), por repetição (repetir é provar a veracidade de um conceito) e por convicção (quem confia no que diz tem mais chances de sugestionar).

Desse modo, observa-se que a principal finalidade da publicidade é a incitação. Por meio dos sentidos e das vontades, o interlocutor é convocado à ação, no caso, à compra do produto. Inscrita na ideologia do capitalismo, a publicidade deve ser instigante, deve persuadir, a ponto de convencer as pessoas de que o caminho da felicidade se resume à aquisição de um carro, da roupa da moda, de um refrigerante, de um crédito bancário para financiar a casa dos sonhos. Esse é o modus operandis das grandes companhias que manipulam a sociedade, reduzindo a busca interior a um bem material que logo se tornará obsoleto, e um novo 
ciclo será iniciado com um produto ainda mais moderno e potente.

No próximo tópico, analisaremos três peças publicitárias, considerando as noções de sujeitos do ato de linguagem, o processo de semiotização do mundo, o contrato de comunicação, e os imaginários sociodiscursivos.

\section{Análise}

As duas peças publicitárias selecionadas, que serão analisadas a seguir, apoiam-se no aspecto icônico ao utilizar emojis. Com a crescente expansão das redes sociais, seu uso configura uma tendência para a transmissão de qualquer tipo de mensagem, incluindo a publicitária.

Esses signos são um elemento a mais para compor a estratégia de persuasão e de sedução, como também, comunicar e propagar representações sociais que influenciam o comportamento e impõem hábitos a um grupo.

A produção de uma peça publicitária capta o mundo a significar e, pensando no Tu-destinatário - o público a que se destina, transforma-o em um mundo de maravilhas e de facilidades, que é construído por meio da escolha da tipografia, das imagens, das cores, dos ângulos e dos enquadramentos de cada elemento presente na cena.

Analisaremos, nesta seção, duas peças publicitárias. A primeira é da marca de sabão de roupa Omo (Figura 5) e a segunda, da marca de automóveis Chevrolet (Figura 6).

Figura 5 - Peça publicitária de Omo Multiação

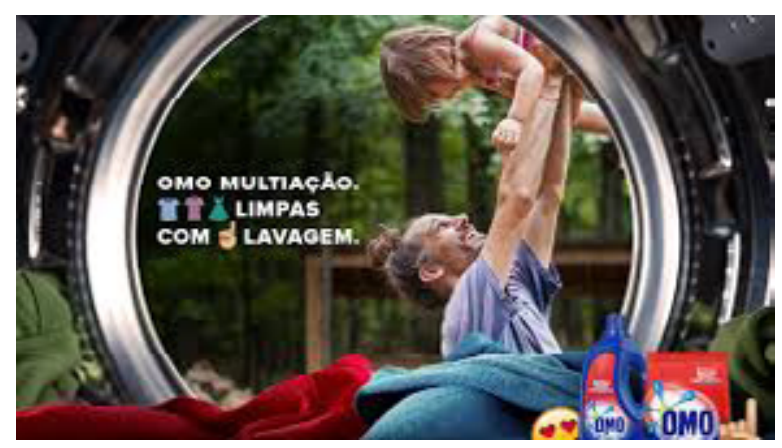

Fonte: https://portal.comunique-se.com.br/omo-estreia-campanha-com-linguagem-digital/, 2017

Consolidada no Brasil há mais de 60 anos, a marca Omo investe maciçamente no marketing e na publicidade, veiculando, diariamente, anún- 
cios em TV e em revista, além de divulgá-los nas redes sociais: Facebook, Twitter e Youtube.

A campanha do sabão Omo Multiação apoia-se em duas mensagens uma no plano denotativo e outra, no conotativo. Segundo Barthes (1990, p. 32), "toda imagem é polissêmica; implica uma cadeia flutuante de significados, dos quais o leitor escolhe alguns e despreza outros". Devido à polissemia icônica, as imagens ancoram-se no texto linguístico, que orienta o sujeito receptor para determinado sentido. Na publicidade, a imagem necessita do texto linguístico para fixar os sentidos privilegiados, de sorte a favorecer a compreensão e a eficácia da mensagem.

Em relação à peça publicitária do sabão em pó Omo, a primeira mensagem, no plano denotativo, é expressa no texto verbal, colocando o produto como aliado do consumidor.

A presença de emojis no lugar dos signos linguísticos "roupas" e "uma" reforçam a intenção do Eu-comunicante que é, por meio do caráter informal do texto, aproximar-se do leitor, envolvendo-o em uma atmosfera de confiança, como faz um bom conselheiro. Se o produto é consumido massivamente pelas camadas A e B da sociedade, por outro lado, a camada mais popular é atraída não só pela qualidade do produto, mas também pela informalidade expressa nos elementos que estão na superfície do enunciado.

A segunda mensagem, expressa pela imagem do anúncio, encontra-se no plano conotativo. A partir do momento em que o consumidor opta pela marca Omo, além do benefício de ter roupas limpas com apenas uma lavagem, ele terá adquirido também mais tempo para cuidar da família.

Um ponto a ser destacado está relacionado à questão dos estereótipos ${ }^{3}$. Em nossa sociedade, por muitos anos, as campanhas de produto de limpeza eram estreladas por atrizes que representavam a dona de casa.

No entanto, o leitor é surpreendido ao visualizar um homem sendo responsável pelas roupas e pelo cuidado com o filho. Até bem pouco tempo, a sociedade ocidental tinha a visão estereotipada de que os serviços de casa e a educação dos filhos eram responsabilidade da mulher, enquanto ao homem cabia o papel de provedor. Após lutas e movimentos em favor da igualdade de gênero, verificou-se que esse tipo de representação social está perdendo lugar nos imaginários coletivos e outros tipos estão emergindo como o exposto na campanha de Omo.

Outra interpretação possível é que o homem visto de dentro da máquina 
de lavar roupa não significa necessariamente que ele é o responsável por essa tarefa doméstica. Ele aparece brincando com o filho. As publicidades, normalmente, atribuem ao homem/pai o papel do lazer, de exercer uma atividade lúdica com a criança, enquanto à mãe cabe a manutenção da casa. Com o auxílio de Omo, o pai pode brincar sem se preocupar em sujar, pois o sabão daria conta da limpeza, com o máximo de eficiência. É possível afirmarmos que o Eu-comunicante, compósito, neste caso, por englobar todos os envolvidos na criação da peça publicitária, construiu um Eu-enunciador na figura de um conselheiro e um Tu-destinatário que tanto pode ser a dona de casa, como é visto tradicionalmente, como o pai que, no contexto da sociedade atual, vem assumindo também a responsabilidade no cuidado do lar e dos filhos.

No que tange à composição da imagem como um todo, observamos a cena como se estivéssemos dentro da máquina lavadora, onde vemos as roupas e a moldura da porta da máquina pela qual se visualiza o homem brincando com o filho, ocupando o ponto central entre o texto verbal e o produto da marca, que aparece junto às roupas do lado de dentro da lavadora, acompanhado por um emoji de rosto apaixonado e outro emoji atuando como índice/símbolo ${ }^{4}$ de "uma lavagem". Pode-se dizer que o foco do anúncio recai sobre o consumidor, representado pelo ator, e não sobre o produto da marca que, apesar de estar em primeiro plano, aparece em proporção menor no canto inferior direito, de acordo com o padrão dos textos publicitários.

Outro ponto a se destacar diz respeito ao processo de semiotização (CHARAUDEAU, 2005) que, conforme observado anteriormente, desdobra-se em dois processos: de transformação e de transação. No processo de transformação, o produto é identificado pelo nome da marca Omo Multiação e pela sua imagem no canto inferior direito. Embora a qualificação não esteja explícita, pode-se entender que Omo é o melhor sabão em pó do mercado devido ao argumento "roupas limpas com uma lavagem".

Tanto a ação quanto a causação se confundem quando pensamos que os seres agem e sofrem ações que os colocam em relação de causa e efeito. No caso da peça publicitária da figura 5 , a ação de ter roupas limpas com uma lavagem tem como causa a escolha pelo sabão Omo.

O processo de transformação não ocorre sozinho, mas considerando a si-

\footnotetext{
4 Segundo Peirce (2005), criador da ciência Semiótica, em linhas gerais, na relação entre signo e referente, o ícone é um signo que representa seu objeto por similaridade; o índice é um signo que indica outro objeto, por contiguidade, sendo acionado pela memória da pessoa que a ele recorre; e, por último, o símbolo é um signo que representa o seu objeto por meio de uma relação arbitrária e/ou convencional.
} 
tuação imposta pelo processo de transação, que, nesse caso, é o anúncio de um produto. O princípio de alteridade sobressai-se nas identidades de anunciadores e consumidores que, na cena enunciativa, são o Eu-enunciador (conselheiro) e o Tu-destinatário (dona de casa ou pai de família). A fim de que o contrato de comunicação seja bem sucedido, é necessário que se estabeleça um vínculo entre os sujeitos por meio dos princípios da influência, o argumento de ter as roupas limpas na primeira lavagem; e da pertinência, que preconiza que ambos devem compartilhar dos mesmos valores sociais. No caso, o Eu-comunicante, a fim de atingir tanto o público moderno quanto o mais tradicional, apoiou-se em dois imaginários discursivos: um mais moderno, que reflete uma sociedade que luta pela igualdade na distribuição de tarefas domésticas entre homens e mulheres; e um mais conservador, que vê a mulher como a responsável pelas tarefas domésticas e o pai como aquele que diverte o filho. O princípio de regulação, que diz respeito às estratégias utilizadas para incitar o interlocutor, é reforçado pelos emojis, que dão um caráter informal à publicidade e, também, um caráter moderno à marca, seduzindo o leitor/consumidor.

A peça seguinte, da figura 6, foi elaborada nos Estados Unidos para lançar o novo Cruze da marca Chevrolet.

Figura 6 - Peça publicitária do Novo Chevrolet Cruze

PREPARE TO FALL IN LOVE.

Words alone can't describe the all-new 2016 chevrolet Cruze.

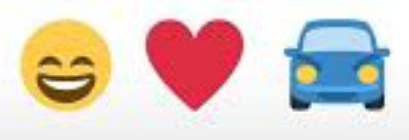

Fonte: http://www.brandchannel.com/2015/06/22/chevrolet-emoji-062215/, 2015.

No texto publicitário da figura 6 , verifica-se o argumento de que o carro é capaz de suscitar a paixão no leitor por meio do texto: "Prepare-se para se apaixonar. Palavras sozinhas não podem descrever o novo Chevrolet Cruze 2016".

A frase com emojis, ancorada pelo verbal, mobiliza as emoções, logo, faz com que o leitor acesse os imaginários e o estereótipo de que o carro é o objeto de desejo de todo cidadão. A estratégia adotada pelo Eu-comunicante inclina-se 
para a sedução e a persuasão.

Observa-se que a marca Chevrolet já está consolidada no mercado e não necessita de estratégias mais fortes para captar o leitor. Visualmente, a imagem do coração ocupa uma posição central no anúncio, sendo a conexão entre o leitor representado pelo emoji sorridente e o carro. O próprio texto verbal afirma a importância da imagem para produzir efeitos, que, no caso, é a exaltação do sentimento e da emoção, e que, na visão estereotipada, deve ocupar lugar central em nossas vidas. Esse é o argumento que leva à compra por impulso.

Na mise en scène, identificamos o Eu-enunciador que apresenta o produto, qualificando-o como all-new (todo novo). A ação é colocada no imperativo pelo verbo prepare (prepare-se). A relação de causação faz-se quando o Tu-interpretante, ao conhecer o produto, sofre a consequência de se apaixonar e desejar e, por conseguinte, adquiri-lo. Assim, o princípio de alteridade apresenta-se no momento em que o Eu-comunicante projeta um tu-destinatário conectado às últimas tendências no que se refere à maneira de se comunicar. O princípio de regulação evidencia bem a intenção do Eu-comunicante ao empregar o uso de emojis junto ao texto verbal, como fazemos nas redes sociais com aqueles com quem temos uma relação amigável ou familiar. A regulação nos conduz ao princípio de influência, que é manifestado à medida que a finalidade do Eu-comunicante é alcançada, ao despertar o interesse do consumidor pelo produto. Os saberes e os valores compartilhados nessa peça, em que figura o princípio de pertinência, dizem respeito ao fato de o carro não apenas ser um meio de transporte, mas uma referência de status social.

Verifica-se, portanto, o caráter simbólico e social do ato de adquirir um automóvel. Nos imaginários sociais, tanto das elites, quanto das camadas populares, o automóvel representa status e poder. Apesar de desprezado discursivamente por alguns grupos, ainda é aclamado como um objeto de desejo. O carro é muito mais que um veículo utilitário que leva e traz pessoas, demarca um lugar na sociedade e é indicativo de uma determinada posição na hierarquia social. Desse modo, o consumo, mais especificamente de automóveis, por estar associado à exibição pública, é um meio pelo qual as pessoas se distinguem e fomentam diferenças e desigualdades em relação a outros indivíduos e grupos sociais.

\section{Considerações Finais}

No contexto da cibercultura, as marcas adotam cada vez mais estratégias 
de comunicação focadas na proximidade, com o objetivo de influenciar o consumidor e aproveitar seu crescente poder de expressão para gerar maior visibilidade.

Neste estudo, de acordo com os objetivos traçados inicialmente, examinamos a construção da argumentação icônico-linguística com os emojis e como esses elementos são afetados pelos imaginários sociodiscursivos.

O primeiro aspecto a ser ressaltado relaciona-se à noção de identidade discursiva dos atores na mise en scéne publicitária. $O$ anunciante aparece sob a máscara de um Eu-eunciador que se coloca como benfeitor ao apresentar um produto capaz de satisfazer às necessidades e aos desejos do Tu-destinatário, a imagem que o anunciante projeta do público, que tanto pode ser um consumidor potencial ou efetivo.

Nas publicidades, ressoam imaginários e representações sociais, além de saberes de conhecimento e, principalmente, de crença. Logo, é possível perceber que o sujeito enunciador apropria-se, muitas vezes, de imaginários sociodiscursivos de nosso mundo real para estruturar seu próprio discurso. Observamos, assim, que a dinâmica do consumo envolve não só a aquisição de um bem, mas de uma forma de sociabilidade.

Embora os emojis sejam facilmente compreendidos por falantes de toda parte do globo, seus sentidos estão ancorados no texto verbal. Em todas as peças, os emojis atuam como elemento de sustentação, reforçando o texto verbal.

O segundo objetivo deste estudo foi identificar os imaginários evocados nas publicidades, a partir de estereótipos. Se considerarmos o contexto social atual, no qual se luta pela igualdade de gêneros, observamos, na peça publicitária da figura 5, uma possível modificação nos imaginários, uma vez que o anúncio concede ao leitor uma interpretação que o desloca do estereótipo tradicional. $\mathrm{Na}$ análise da peça publicitária da figura 6 , constata-se que o consumo está associado a uma exibição pública, que remete à busca de dignidade e de virtuosidade. Dar visibilidade à ação de consumir diz respeito à busca de valor em uma determinada comunidade, cujos membros se comparam e se distinguem uns dos outros.

O automóvel é parte de um processo de identificação e de pertencimento a uma determinada categoria na estratificação social, que, atualmente, ocorre, sobretudo, nas redes sociais digitais. Tanto o texto verbal, quanto o visual, com a presença de emojis, apenas confirmam um estereótipo que foi criado e, posteriormente, absorvido ao imaginário da sociedade ocidental, à medida que a 
indústria automobilística se desenvolvia.

A confirmação ou deslocamento de determinada crença pode suscitar diversos efeitos. Com base nas análises, apesar de reproduzir estereótipos que já são parte dos imaginários coletivos, os emojis são utilizados em textos publicitários como uma estratégia de captação, pois refletem uma identidade coletiva de pertencimento à rede. Desse modo, despertam a atenção e a empatia do público, além de estabelecerem uma cumplicidade, tirando o consumidor da indiferença. Constata-se, portanto, que, para a publicidade, é mais seguro reproduzir os estereótipos que já são parte dos imaginários do que propor algo novo.

\section{Referências}

AMOSSY, R.; PIERROT, A. H. Estereotipos y clichés. Buenos Aires: Eudeba, 2001.

CHARAUDEAU, P. Os estereótipos, muito bem. Os imaginários, ainda melhor. Trad. André Luiz Silva e Rafael Magalhães Angrisano. In: Entrepalavras. Fortaleza, v. 7., p. 571-591, já./jun. 2017.

. Imagem, mídia e política: construção, efeitos de sentido, dramatização, ética. In: MENDES, E.; MACHADO, I. L.; LIMA, H.; LYSARDO-DIAS, D. (Org.) Imagem e discurso. Belo Horizonte: FALE/UFMG, 2013, p. 383-405.

Identidade social e identidade discursiva, o fundamento da competência comunicacional. In: PIETROLUONGO, M. (Org.) O trabalho da tradução. Rio de Janeiro: Contra Capa, 2009, p. 309-326.

Disponível em: http://www.patrick-charaudeau.com/Identidade-social-e-identidade.html. Acesso em 15/10/2017

Uma análise semiolinguística do texto e do discurso. In: PAULIUKONIS, M. A. L.; GAVAZZI, S. (Orgs.). Da língua ao discurso: reflexões para o ensino. Rio de Janeiro: Lucerna, 2005, p. 11-27.

. Visadas discursivas, gêneros situacionais e construção textual. In: MACHADO, I. L.; MELLO, R. de (Orgs.). Gêneros: reflexões em análise do discurso. Belo Horizonte: Nad-FALE UFMG, 2004, p. 13-42.

. Uma teoria dos sujeitos da linguagem. In: MARI, H.; MACHADO, I. L.; MELLO, R. de (Orgs.). Análise do discurso: fundamentos e práticas. Belo Horizonte: Nad-FALE-UFMG, 2001, p. 23-37.

DEWAR, R. Design and evaluation of public information symbols. In: Visual Information for everyday use: design and research perspectives. London: Taylor \& Francis, 1999.

KRESS, G.; VAN LEEUWEN, T. Reading images: the grammar of the design visual. London: Routledge, 1996.

MONNERAT, R. M. A publicidade pelo avesso. Niterói: EDUFF, 2003. 
PEIRCE, C. S. Semiótica. 3a.ed. São Paulo: Editora Perspectiva, 2005.

\section{Sobre os autores}

Marcia Figueiredo de Assis Terra - Mestre em Letras pelo Programa de Pós-Graduação em Estudos de Linguagem da Universidade Federal Fluminense (UFF); Niterói-RJ. E-mail: mafaterra@gmail.com. Lattes: http://lattes.cnpq.br/4905809969195543. OrclD: https:// orcid.org/0000-0002-8795-7731.

Ilana da Silva Rebello - Doutora em Letras. Professora do Programa de Pós-Graduação em Estudos de Linguagem da Universidade Federal Fluminense (UFF); Niterói-RJ. E-mail: ilanarebello@id.uff.br. Lattes: http://lattes.cnpq.br/3408468123212172. OrclD: https://orcid. org/0000-0002-3032-604X. 